\title{
A Study of Teaching Techniques Used By The Teachers of Speech Impaired Students and The Influences Towards Learning Achievements in Tenth and Eleventh Grade at SLB Dharma Bhakti Dharma Pertiwi in Academic Year 2017/2018
}

\author{
Ayu Aprillia ${ }^{1}$, Dameria Magdalena Sidabalok ${ }^{2}$
}

${ }^{1}$ Department of English Education, Universitas Bandar Lampung, ${ }^{2}$ Department of English Education, Universitas Bandar Lampung

\section{ARTICLE INFO}

Keywords:

Teaching techniques, teaching English, speech impaired students, teaching speech impaired students, learning achievement,

\begin{abstract}
The objectives of this research are to know the techniques used by the teacher in SLB Dharma Bhakti Dharma Pertiwi to teach English for speech impaired students, and to know how the techniques influence the students learning achievement. The research was done at SLB Dharma Bhakti Dharma Pertiwi in tenth and eleventh grade class in speech impaired class that consisted of 7 and 6 students. Data gathering was done by doing observation and interview to two teachers from ten and eleventh class. The results show that both teachers used mixed techniques in teaching English for speech impaired students. The teacher used some techniques like demonstration, repetition, and discussion. Demonstration can be done by showing pictures, using tools and touching the under part of the chin to teach pronunciation. Repetition can be done by repeating the words for many times to make the students remember. Discussion can be done by asking them questions to make the students active in the class. Some techniques were appropriate to improve students learning achievement but, there was a technique also that did not have a big impact in improving students learning achievement. By doing this research, it will help us to determine techniques in teaching speech impaired students. We know which technique that can help us to improve students learning achievement. It will help the students to get a better teaching learning process if we already know how to teach them.
\end{abstract}

This is an open access article distributed under the terms of the Creative Commons Attribution 4.0 International License, which permits unrestricted use, distribution, and reproduction in any medium, provided the original work is properly cited. ( 2019 Ayu Aprillia, Dameria Magnalena Sidabalok.

\section{INTRODUCTION}

Teachers nowadays are required to teach creatively. Teaching creatively has been defined as teachers using imaginative approaches to make learning more effective, interesting, and exciting. Using some strategies in teaching can help teacher build creativity. Teacher should find an appropriate technique to teach their students. Moreover for special student like speech impaired

${ }^{1}$ Corresponding author's address: Department of English Education, Universitas Bandar Lampung, Bandar Lampung, Indonesia e-mail: ayuuapr27@gmail.com

${ }^{2}$ Corresponding author's address: Department of English Education, Universitas Bandar Lampung, Bandar Lampung, Indonesia e-mail: dameria.sidabalok@ubl.ac.id 
students who needs more attention in teaching we should know how to teach them. Speech impairment is a condition when the ability to produce speech sounds that are necessary to communicate with others is impaired. There are four major areas in these impairments that defined by the nation's special education law, the Individuals with Disabilities Education Act (IDEA). The first is articulation disorder. People with articulation disorders have difficulty in making certain sounds. These sounds may be left off, added, changed, or distorted, that makes it hard for people to understand their words. The second is Fluency disorder. People with fluency disorder having something that disturbing the rhythmic of speech. It makes the child's speech contains of repetitions, hesitations, prolongations, or disturbances. The third is voice disorder. It happens when the child's voice has an abnormal quality in pitch, resonance, or loudness. The last is Language disorder. This is the condition where people have problems in expressing their needs, ideas, or information, and they have difficulty in understanding what others are saying. From the explanation above we know the reason why many speech impaired students are unenthusiastic to participate in activities that require speaking.

Zebron (2015) says that it has been recognized that learners with communication disorders have serious insufficiencies in their ability to communicate with people. Usually a communication disorder happens in their ability to use language, speech and hearing. Students with communication disorder have many different symptoms. It's like difficulty in following teacher directions, they also have problems in pronouncing words, it's hard for the students to express themselves, they have problems in paying attention to a conversation, problems in understanding what the teacher was said, and challenges of being understood because of unclear pronunciation. Students with communication disorder also have difficulty in learning new vocabulary, understanding questions, recalling information, understanding and remembering the words, learning the alphabet, identifying sounds that resemble to letters, distinguishing the correct orderof letters in words, and possibly, spelling. Their difficulties with speech may include being unintelligible due to poor learning (Zebron, 2015).

Students with speech and hearing impairments also need comprehensive evaluation in order to develop specific, appropriate academic goals to each student. It should be seen from the child's cognitive potential such as, thinking skills, communication skills, learning style, and academic abilities when making critical decisions (Center for Deaf and Hard of Hearing Education, 2014). It supported by statements from Michelon P. (2006) Thinking skills here means recognition and interpretation of sensory stimuli. Communication skills is how the students talking and understanding the language. Learning style is Ability to sustain concentration on a particular object, action, or thought, and ability to manage competing demands in our environment, and academic abilities means how the students defining the problem in the right way to then generate solutions and pick the right one and the ability to make decisions based on problem-solving. From the explanation above I want to find the techniques used by the teacher in teaching students with speech impairment. I want to know what techniques that appropriate with students with speech impairment. That is the reason I do this research.

Students with speech and hearing impairments also need comprehensive evaluation in order to develop specific, appropriate academic goals to each student. It should be seen from the child's cognitive potential such as, thinking skills, communication skills, learning style, and academic abilities when making critical decisions (Center for Deaf and Hard of Hearing Education, 2014). It supported by statements from Michelon P. (2006) Thinking skills here means recognition and interpretation of sensory stimuli. Communication skills is how the students talking and understanding the language. Learning style is Ability to sustain concentration on a particular object, action, or thought, and ability to manage competing demands in our environment, and academic abilities means how the students defining the problem in the right way to then generate solutions and pick the right one and the ability to make decisions based on problem-solving. From the explanation above I want to find the techniques used by the teacher in teaching students with 
speech impairment. I want to know what techniques that appropriate with students with speech impairment. That is the reason I do this research.

\section{LITERATURE REVIEW}

Teaching is the imparting of knowledge by a teacher or other knowledgeable person (Wikipedia, 2017). Based on the explanation above we know that teaching is a process of giving an information or knowledge to our students. In the general area of teaching methodology, we will find people talk about approaches, methods, procedures, and techniques. Educational research techniques (2015) explain that "Approaches are a theory about language learning or even a philosophy of how people learn in general".

The approach is a way of looking at teaching and learning. Underlying any language teaching approach is a theoretical view of what language is, and of how it can be learnt. An approach gives rise to methods, the way of teaching something, which use classroom activities or techniques to help learners learn. Method is an application of an approach in the context of language teaching (Educational research techniques, 2015), for instance, direct method. This method uses repetition in explaining the material, so it will help the students in memorizing the word because they hear it continuously.

Educational research techniques (2015) tell that technique is a single activity that comes from a procedure. One of the examples of teaching technique is Flipped Classroom. In this technique teacher will give the students topic about the next material. Students should prepare the material for the next meeting, and they will explain to their friends about the material that they have prepared before. It will encourage students to prepare for the lesson before class (Santos, 2013). There are various kinds of techniques that can use by teacher in teaching.Especially teaching students with special needs.

There are many reasons that make people get communication disorders. For example, Zebron (2015) tells that language-based learning disabilities come from differences in brain structure at birth. In most cases, this communication disorder is genetically based. Other communication disorders are a result of oral-motor difficulties such as difficulties resulting from a stroke which may involve motor, traumatic brain injuries, speech or language problems, and stuttering, which is now believed to be a neurological deficit.

Zebron (2015) says that it has been recognized that learners with communication disorders have serious insufficiencies in their ability to communicate with people. Usually a communication disorder happens in their ability to use language, speech and hearing. Language difficulties are divided into spoken language, writing and reading difficulties. Speech disorders focus on the articulation and phonology, fluency, and voice. Hearing difficulties express themselves in speech problems as in articulation / voice and language problems. Examples of hearing impairments include deafness and hearing loss, which can result from a conductive loss, a sensor neural loss, a mixed loss, or a central hearing loss (Zebron, 2015).

Zebron (2015) explains that students with communication disorder have many different symptoms. It's like difficulty in following teacher directions, they also have problems in pronouncing words, it's hard for the students to express themselves, they have problems in paying attention to a conversation, problems in understanding what the teacher was said, and challenges of being understood because of unclear pronunciation, but Susanto and Nanda (2018) stated that students with special needs actually can have unique ways of learning foreign language and these abilities should be acknowledged to obtain the perspectives of students who receive disability specific education. 
Students with speech and hearing impairments also need comprehensive evaluation in order to develop specific, appropriate academic goals to each student. It should be seen from the child's cognitive potential such as, thinking skills, communication skills, learning style, and academic abilities when making critical decisions (Center for Deaf and Hard of Hearing Education, 2014). It supported by statements from Michelon P. (2006) Thinking skills here means recognition and interpretation of sensory stimuli. Communication skills is how the students talking and understanding the language. Learning style is Ability to sustain concentration on a particular object, action, or thought, and ability to manage competing demands in our environment, and academic abilities means how the students defining the problem in the right way to then generate solutions and pick the right one and the ability to make decisions based on problem-solving.

\section{METHODOLOGY}

The study of this research was case study. Case study research is a qualitative approach in which the researcher explores a case in detailed involving multiple sources for instance, observations and interview (Creswell, 2007, p.73). I used this approach because it is suitable to my research problems. I described the students' learning process along with the techniques used by the teacher, and how the techniques influence students' learning achievement. According to Creswell (2007, p.73) I used two ways in conducting this research. First, I observed the class and the teacher teaching techniques, and then interviewed the teachers. Observation notes and teachers respond to the interview questions became the primary data. Finally, all of the data will be analysed and described based on the problems of the research.I did the research at tenth and eleventh grade of speech impaired class in SLB Dharma Bhakti Dharma Pertiwi Bandar Lampung. In the research, there were 7 students in grade ten and 6 students in grade eleven of speech impaired class of SLB Dharma Bhakti Dharma Pertiwi Bandar Lampung. There were 3 boys and 4 girls in grade ten and 6 boys in grade eleven who were students of speech impaired class of SLB Dharma Bhakti Dharma Pertiwi Bandar Lampung.

Firstly, I did identification for the research problems. There were the general problems appeared when this research would be conducted. To find the problems, I reviewed on some literature that is suitable with the topic to get more information about the problems. Next, I identify the research questions that become the baseline in doing the research after getting information from some literature that has connections with the research topic. After reviewing all the theories, I began to collect the data based on the method used in this research. There were identifying the participants and the place for doing this research, getting the permission from the school in doing this research, deciding the instruments for collecting the data, finally choosing the way in analyzing the data after all of them were gathered by me.

The data were collected by using two instruments. First, an observation which was done in order to picture the students' learning process. In this observation I took a role of Nonparticipant Observer. For the observation part, the first step of analyzing the data was transcribing the data. Creswell (2012, p. 239) said that transcription is the process of converting audiotape/video recordings into text data. The further process of analyzing text in qualitative research was code the data. According to Creswell (2012, p. 243) Coding was the process of dividing and labeling text to form descriptions and broad themes in the data. For instance, after dividing the information become some codes concerning about setting, process and activities, I wrote down the description for each code. It was very helpful in making conclusion from the data analysis. Then, I summarized in detail the findings from the data analysis in form of writing narrative discussion. Similar procedures have done in analyzing the data from the interview. After analyzing the data from the interview and the observation, the conclusion have been formulated in order to present the general result of the research. 


\section{DISCUSSION}

\section{The techniques used by the teacher in teaching English for speech impaired}

Based on the observation in the first meeting, the students were lack of interest in learning English. It could be seen when the teacher asked about the meaning of the words and they said "Lupa". It means they did not remember the previous lesson. After saying they forgot, the teacher will ask them to open the book and asked them to come in front of answering the questions. Even they were lack of interested in learning English, but the students were confidence to come in front to answer the questions even if it is wrong. The problem was about their intelligence. Zebron (2015) said that students with speech and hearing impairments are also lacking knowledge. It was proved by seeing their learning process in the class. The students were hard to remember the words in English. They need more time to understand something. That is why it is hard for the students to remember a lot of material.

From thesecond observation, the students were more enthusiastic about learning technique that the teacher used today. The picture can help them in memorizing the words quickly. There were improvements in students' confidence when they learned English in the class. I saw that the students were not afraid to do wrong when they were doing the assignment and they could do the assignment with their own ability. They also did not say "Lupa" when the teacher asked them about the lesson. They tried hard to remember the word from the previous lesson. They also tried hard to pronounce the word well. They tried it many times until they can pronounce the words well.

Based on the result of the observation, the students' English skills were low. It could be seen when the teacher asked about the previous material. They did not remember the previous lesson. It is like what Zebron (2015) said that students with speech and hearing impairments are also lacking of knowledge and students with communication disorder also have difficulty in learning new vocabulary. They need more time to understand something. That is why it is hard for the students to remember a lot of material. The teacher faced this problem by using repetition technique. By repeating the words for many times, it will help the students to remember the words. The teacher not only used repetition techniques but also gave a real example in explaining the words for instance, showing a picture or giving real tools. The other problem that appeared when taught students with speech and hearing impairment was the pronunciation.

Zebron (2015) explained the students with speech impairment are hard in learning the alphabet and identifying sounds that resemble letters. That is why by asking the students to touch their under part of the chin and using paper to teach pronunciation are the techniques that the teacher use in teaching English. By touching the teacher and their under part of the chin the students can feel the mouth movement and the vibration that come from different sounds. They can compare the movement between their mouth movement and their teacher mouth movement. If the students' mouth movement is the same with the teacher, it means they produce the right pronunciation. The aim of using paper is to explain the words that produced air when we want to say it. For instance, for the word "flash", the teacher said if the paper was moved when they said the word so it was true but, if the paper was not moved it means they are wrong.

There are some tips for the teacher that Cooley (2007) tells when they teach students with communication disorder. There are showing understanding, patience, and acceptance to the students. Based on the interview result we can see that the teachers in there are very patience in teaching the students because they taught them individually. In interview (H19) the teacher said that if in SLB they taught them individually.

"If in SLB it focuses on individual learning so, the teacher should handle the students one by one. (interview-H19)" 
It can be seen from the statement the teacher cannot teach them in group because each student has different ability in learning. They also cannot use only one technique to teach the students. Based on the interview, all the teachers said that they did not use only one technique but they compare all the technique when they taught.

"Mixed method, what are the suitable methods for the students for example like demonstration, observation. Sometimes I bring the students outside the class to explain about tree. The students feel happy if I explained the name of the tree by showing the real example. The name of this tree is this and the other tree named is that. It will be more effective (interview-H2O)".

The aim of using demonstration techniques is to make the students more understand about the words and they will remember it for a long time. The example of the observation technique was brought the students outside the class then the teacher told the students to observe the tree from the name of the tree until the usage of the tree and etc. And, the aim of using discussion technique is to do the interaction with the students to make them active in the class by asking them several questions and told them to come in front. I have made a table to see how the teacher used the techniques to each student. Based on the result of observation and interview, the teacher taught the students with more than one technique. The teacher combined the techniques to make the students easier in learning English. The teachers also use different techniques for each student because each of them have different ability. The teacher used different techniques in teaching pronunciation and teaching the meaning of the words

\section{The influence of teachers' teaching techniques towards students learning achievement}

The second discussion focuses on knowing the student improvement during their learning process with some various techniques used by the teachers. The explanations are discussed into some points. They are communication skills, thinking style, learning style, and academic abilities when making critical decisions.

According to the statements from Michelon P. (2006) saying that Communication skills is about how the students talk and understand the language. The students in the tenth grade were able to communicate well by using those techniques. That means the students in the tenth grade have achieved one of the learning objectives for deaf and speech impaired students. It is different from the students in the eleventh grade. They have not achieved the learning objectives yet as they had not acquired the appropriate way to pronounce certain English words.

The next point is about the student thinking skill. It concerns on students' recognition and interpretation of sensory stimuli like seeing, smelling, touching, hearing, etc. (Michelon P., 2006). Both of the teachers in tenth and eleventh grade used demonstration techniques like showing a picture or real tools. Furthermore, based on the interview result, the teacher said that the most suitable techniques were demonstration, observation and discussion. It means that showing the students a real example helped them to recognize the tools name for instance the word "book". The teacher then showed them a real book to explain the meaning of the word "book". By showing it, the students could see and feel the book and it helped them to understand and remember the meaning of the word for a long time. By using these techniques both the classes can improve the term in thinking skills.

The other point in students' learning achievement is learning style. It is the ability to sustain concentration on a particular object, action, or thought, and ability to manage competing demands in our environment (Michelon P., 2006). It can be seen from both classes, the tenth and eleventh grade students, which were active in the class. The teachers used discussion technique to make the students active. We can see from the observation result. The teacher always did the communication to the students. Based on the result from the interview and observation, I saw that the students in both classes could manage their learning style. 
The last point of students' learning achievement is about their academic abilities when making critical decision. It focuses on the way of the students define the problem in the right way to then generate solutions and pick the right one and the ability to make decisions based on problemsolving. From the observation result of students in tenth grade, I could see how the teacher discussed the problems that appear in the class. One example was when one student was late and then teacher asked the other students about how to resolve the problem. By using this technique, it helped the students to make a decision to solve the problem and, from both classes, I could see how the technique was appropriate in improving the student academic abilities in making decision.

\section{CONCLUSION}

Students with speech impairment have many difficulties in learning. Therefore, being a teacher for speech impaired students is not an easy work. They should use various techniques to help them in learning. It can be seen from the result of the observation and interview showing about how the teacher taught the students. The teacher used some techniques like demonstration, repetition, and interaction. Demonstration can be done by showing pictures, using tools and touching the under part of the chin to teach pronunciation. Repetition can be done by repeating the words for many times to make the students remember. Discussion can be done by asking them questions to make the students active in the class.

Both of the teacher used mixed techniques in teaching English but, there was a differences in students learning achievement. The students in tenth grade had an improvement in communication skills after the teacher taught them how to pronounce the words by using paper and touching the under part of the chin. It was different from eleventh grade students. The teachers focused in repetition technique and not focus in students' pronunciation, so their improvement in communication skill was not really significant. In the other terms like thinking style, learning style, and academic abilities when making critical decisions the students showed an improvement when they learned by using these techniques.

It can be concluded that there were some techniques used by the teachers in teaching English. Some techniques were appropriate to increase students learning achievement and, the other was not really work to improve students learning achievement. By using demonstration techniques like showing a picture and do the observation, it was helpful in improving students learning style and thinking skills. When the teacher used discussion in solving the problem in the class it can help the students to improve their academic abilities in making critical decision. The use of repetition technique in teaching students' pronunciation does not give significant improvement. If the teacher not only use repetition technique but also explain the pronunciation using paper or hands, it will improve the students' communication skills better than using a single technique.

\section{REFERENCES}

Cooley, M.L. (2007).Teaching kids with mental health and learning disorders in the regular classroom. MN: Free Spirit Publishing Inc. Creswell, J. (2007). Qualitative inquiry \& research design; Choosing among five approaches.

Creswell, J. W. (2007).Qualitative inquiry \& research design; Choosing among five approaches.

Creswell, J.W. (2012). Educational Research Planning, Conducting, andEvaluating Quantitative and Qualitative Research. Boston, USA: Pearson Education, Inc.

Educational Research Techniques. (2015, March 16). Approach, Method, Procedure, and Techniques In Language Learning [Blog post]. Retrieved from https://educationalresearchtechniques.com/2015/03/16/approachmethod-procedure-andtechniques-in-language-learning/

Guidelines for the Assessment and Educational Evaluation of Deaf and Hard of Hearing Children 
in Indiana. . (2014). Indianapolis, Indiana: The Center for Deaf and Hard of Hearing Education. Retrieved from https://www.in.gov/isdh/files/Assessment_Guideline finalized_January_2015.pdf

Michelon P. (2006). What are Cognitive Abilities and Skills, and How to Boost Them? Sharp Brains [Blog post]. Retrieved on December 18,2018from https://sharpbrains.com/blog/2006/12/18/what-are-cognitive-abilities/

Santos, D. (2013, September 17). Teaching Techniques. Go Conqr. Retrieved from https://www.goconqr.com.

Susanto \& Nanda, D.S. (2018). Teaching And Learning English or Visually Impaired Students: An Ethnographic Case Study.Journal of English Education,7, 83-91.

Wikipedia. (2017). Teching Method. Retrieved from https://en.wikipedia.org/wiki/Teaching_method from

Zebron, Isaac, Maxwell. (2015). Classroom Challenges: Working withPupils with Communication Disorders. Journal of Education and Practice 2222-288XVol.6, No.9.Retrieved fromhttps://files.eric.ed.gov/fulltext/EJ1082466.p. 